\title{
The Oxidation of Fatty Acids by Mycelium of Penicillium roqueforti
}

\author{
By R. C. LAWRENCE AND J. C. HAWKE \\ New Zealand Dairy Research Institute and Department of Chemistry and Biochemistry, \\ Massey University, Palmerston North, New Zealand
}

(Accepted for publication 3 October 1967)

\begin{abstract}
SUMMARY
Low concentrations of fatty acids with less than 14 carbon atoms were oxidized without a lag phase over a wide range of $\mathrm{pH}$ values by mycelium of Penicillium roqueforti. The effect of the fatty acids upon oxygen uptake by a given weight of mycelium, and the nature of the products of oxidation, were dependent upon the concentration and chain length of the fatty acid and the $\mathrm{pH}$ value of the system. The $\mathrm{C}_{9}-\mathrm{C}_{12}$ fatty acids which showed the greatest inhibitory effect were not oxidized to the corresponding methyl ketone with one less carbon atom in such high yields as the less toxic $\mathrm{C}_{6}-\mathrm{C}_{8}$ acids. The $\mathrm{C}_{6}-\mathrm{C}_{8}$ fatty acids markedly inhibited endogenous respiration at low $\mathrm{pH}$ values but this inhibition was reversed by increasing the $\mathrm{pH}$ value. The toxic effect associated with some fatty acids was less pronounced against mycelium which had been previously shaken over an extended period in phosphate buffer. It is suggested that the cellular regulation of fatty acid oxidation and methyl ketone formation involves deacylation of $\beta$-oxo acyl thiolester which provides an alternative means of recycling coenzyme $A$ when oxidation of acetyl $\mathrm{CoA}$ is impaired.
\end{abstract}

\section{INTRODUCTION}

The ability of growing cultures of fungi to oxidize fatty acids of medium chain length to methyl ketones was first noted by Stärkle (1924), who showed that Penicillium roqueforti and two species of the genus Aspergillus produced methyl ketones when grown for several weeks on fatty acids of intermediate chain length. Moreover, when single fatty acids were used as substrates (Stärkle, 1924; Stokoe, I928; Hammer \& Bryant, 1937) these and certain other species of fungi only synthesized methyl ketones with one less carbon atom. It is not clear however whether the oxidation of fatty acids in the above investigations was the result of spore or mycelial activity. A decline in methyl ketone formation as spores germinate to mycelium has been reported (Thaler \& Geist, I939; Franke \& Heinen, 1958). Gehrig \& Knight (1963) concluded that the capacity of spores of $P$. roquefort $i$ to form methyl ketones disappeared rapidly and progressively as the spores germinated. On the other hand Lawrence (1965 $b, 1966)$ found that the slow rate of formation of heptan-2-one from octanoic acid by resting spore suspensions of $P$. roqueforti was markedly increased by the addition of those amino acids and sugars that stimulate germination of the spores. Reports that low concentrations of fatty acids were oxidized by washed mycelium of various Penicillium species (Rolinson, 1954; Girolami \& Knight, 1955; Vinze \& Ghosh, 1962) would also appear to be in disagreement with the conclusions reached by Gehrig \& Knight (I958, I96I, I963) that hyphal cells of $P$. roquefort $i$ were unable to oxidize fatty acids, regard- 
less of the type of medium in which they were grown. It was not clear whether the uncertainty concerning the ability of fungal mycelium to oxidize fatty acids had arisen from the inhibitory effect of the fatty acids on respiration under certain conditions (Rolinson, 1954). The present work was undertaken in an attempt to clarify the situation.

\section{METHODS}

Gehrig \& Knight (1963) grew mycelium of Penicillium roqueforti on a chemically defined medium developed by Meyers \& Knight (1958), which contains both acetate and oleate initially at $\mathrm{pH} 44^{\circ}$. Preliminary work in the present investigation, however, indicated that mycelium grown at $\mathrm{pH} 4.0$ was about 5 times less active in oxidizing fatty acids than that grown at $\mathrm{pH} 6.5$. As acetate at $\mathrm{pH} 4.0$ has also been reported to be inhibitory towards respiration by yeasts (Neal, Weinstock \& Lampen, 1965), a new chemically defined medium without fatty acids was developed.

Growth medium. After preliminary trials the following defined medium was used: ammonium nitrate, $2 \mathrm{~g}$.; magnesium sulphate $\left(\mathrm{MgSO}_{4} \cdot 7 \mathrm{H}_{2} \mathrm{O}\right)$, 0.15 g.; potassium chloride, $0.25 \mathrm{~g}$.; ferrous sulphate $\left(\mathrm{FeSO}_{4} \cdot 7 \mathrm{H}_{2} \mathrm{O}\right)$, 0.0I25 g. These four components were dissolved in $400 \mathrm{ml}$. water and autoclaved for $20 \mathrm{~min}$. at $\mathrm{I} 2$ pounds/sq.in. (I $8^{\circ}$ ). The brown precipitate which formed was allowed to settle and after $24 \mathrm{hr}$ the supernatant fluid was decanted. A Seitz-filtered solution of Io g. glucose, $0.6 \mathrm{~g}$. potassium dihydrogen phosphate and $0.4 \mathrm{~g}$. dipotassium hydrogen phosphate in $100 \mathrm{ml}$. water, supplemented with $\mathrm{I}$ ml. of a trace element solution (mg./l.) - zinc sulphate, $\mathrm{ZnSO}_{4} \cdot 7 \mathrm{H}_{2} \mathrm{O}, \mathrm{I} 80$; copper nitrate, $\mathrm{Cu}\left(\mathrm{NO}_{3}\right)_{2} \cdot 6 \mathrm{H}_{2} \mathrm{O}$, I5; manganese nitrate, $\mathrm{Mn}\left(\mathrm{NO}_{3}\right)_{2} \cdot 6 \mathrm{H}_{2} \mathrm{O}, 80$; ammonium molybdate, $\left(\mathrm{NH}_{4}\right)_{6} \mathrm{Mo}_{7} \mathrm{O}_{24} \cdot 4 \mathrm{H}_{2} \mathrm{O}$, IO - was then added. This growth medium was initially at $\mathrm{pH} 6 \cdot 5$.

Growth of mycelium. Spores of Penicillium roqueforti, ATcC6989 (American Type Culture Collection, Washington) were grown on slopes of Czapek-Dox agar (Oxoid) at $22^{\circ}$. After 5-6 days the spores were transferred to $100 \mathrm{ml}$. of the medium in $500 \mathrm{ml}$ Erlenmeyer flasks. The suspensions were incubated overnight, without shaking, to allow spore germination and then shaken at $20^{\circ}$ for $24 \mathrm{hr}$. The mycelium was harvested, washed and gently blended with a 'Polytron' homogenizer (Mobil Aaran A.G., Luzern, Switzerland) to free trapped ungerminated spores. The suspension was reinoculated in fresh medium and incubated for a further $24-48 \mathrm{hr}$. This resulted in a uniform and homogenous suspension, providing all organisms with comparable nutritional conditions and equal access to oxygen. The growth was harvested by filtration on a Buchner funnel, resuspended several times in about 21 . distilled water, refiltered and finally suspended in phosphate buffer. The concentration of blended mycelium was adjusted to approximately $\mathrm{IO} \mathrm{mg} . / \mathrm{ml}$. dry $\mathrm{wt}$, the exact concentration being determined by dry weight measurement. The mycelium was finally examined microscopically to ensure that it was free of spores.

Oxygen uptake. Measurements were made manometrically at $27^{\circ}$ in a standard Warburg apparatus (Braun, Model ' $\mathrm{V} 8$ '). $0.2 \mathrm{ml} .20 \%$ (w/v) $\mathrm{KOH}$ was used in the inner compartment of the Warburg flasks unless otherwise stated.

Radioactive measurements. These were done by liquid scintillation techniques as previously reported (Lawrence, 1966).

Estimation of methyl ketones and methyl carbinols. Methyl ketones were estimated by pipetting $\mathrm{I} \mathrm{ml}$. of the contents of the Warburg flasks into $2 \mathrm{ml}$. of 2,4-DNP hydra- 
zine ( $2 \mathrm{~g} .11 .2 \mathrm{~N}-\mathrm{HCl})$ in a stoppered test-tube and the hydrazones estimated as detailed previously (Lawrence, 1965a). For the estimation of methyl carbinols the $\mathrm{pH}$ value of $10 \mathrm{ml}$. medium was adjusted until red to phenolphthalein and then extracted with diethyl ether. This extract was concentrated to about $0.5 \mathrm{ml}$. by carefully removing the ether with a stream of air. Samples (I $\mu \mathrm{l}$.) of the concentrate were analysed in a gas chromotograph (Aerograph Hy-Fi, Model A-60o-B, Wilkins Instrument and Research, Inc.). Columns normally used were either $20 \%$ UCON 50 HB 2000 or $20 \%$ Carbowax 1540 on Chromosorb W (Mesh 30-60), although initially $20 \%$ diethylene glycol succinate (DEGS) on firebrick was used.

Identification of the peaks was accomplished by co-chromatography with authentic samples of heptan-2-ol and heptan-2-one. The retention times of heptan-2-ol relative to heptan-2-one were I.45 on the DEGS column ( $\left.115^{\circ}\right), \mathrm{I}^{\cdot} 78$ with Carbowax $\left(90^{\circ}\right)$ and 2.02 with $\mathrm{UCON}\left(100^{\circ}\right)$ columns. Quantitative measurements were made by measuring the peak areas on the chromatograms with a planimeter. Since the concentration of heptan-2-one was known accurately, that of heptan-2-one could also be determined. Recovery trials of known amounts of heptan-2-one and heptan-2-ol carried out using the procedure above were quantitative $( \pm 5 \%)$ over a range of concentrations of the alchohol and ketone from $0.25-10 \mu \mathrm{moles} / \mathrm{ml}$.

Chemicals. Solutions of the salts of the fatty acids (Applied Science Laboratories, Inc., State College, Pa., U.S.A.) were prepared by adding potassium hydroxide and adjusting to the required concentration. $\left[\mathrm{I}-{ }^{14} \mathrm{C}\right]$ octanoic acid was obtained from The Radiochemical Centre, Amersham, Bucks. $\left[2{ }^{14} \mathrm{C}\right]$ octanoic acid was synthesized by a micro adaptation of the method of Reid \& Ruhoff (1944). The purity of the acid was checked directly by co-chromatography with a pure sample of octanoic acid on a gas chromatograph using a column packing of $20 \%(\mathrm{w} / \mathrm{w})$ DEGS and $2 \% \mathrm{H}_{3} \mathrm{PO}_{4}$ on 60-80 mesh, acid-washed 'Celite 545' (Metcalf, I960).

Heptan-2-ol was synthesized by reducing heptan-2-one with sodium and ethanol (Whitmore \& Otterbacher, 1944). It was purified from unchanged heptan-2-one by shaking with 2,4-DNP hydrazine $+\mathrm{HCl}$ reagent and fractionally distilling under reduced pressure until the alcohol was completely free of ketone. The purity was checked by gas chromatography using a column of $20 \%$ DEGS on chromosorb W (30-60 mesh).

\section{RESULTS}

\section{Effect of growth medium on ability of mycelium to oxidize fatty acids}

Lower yields of methyl ketones from fatty acids were obtained with mycelium grown in Casamino acids $(3 \mathrm{~g} . / 500 \mathrm{ml}$.) than in the defined medium described above. The latter medium was therefore used in all subsequent work. The addition of $\mathrm{C}_{12}$ acid $(2 \mu \mathrm{moles} / \mathrm{ml}$ ) to the growth media increased mycelial growth but the mycelium subsequently showed no enhanced ability to oxidize $C_{12}$ acid.

\section{Effect of age of mycelium}

The age at which the mycelium was harvested markedly affected the ability of the mycelium to oxidize fatty acids. Maximum oxygen uptake and methyl ketone formation in the presence of fatty acids was obtained with mycelium harvested after 48-60 hr. Oxidation of fatty acids was slower with mycelium grown for less than $30 \mathrm{hr}$, in agreement with similar observations by Vinze \& Ghosh (1962). 


\section{Endogenous respiration of mycelium}

In the course of most experiments a change in the rate of oxygen uptake could be clearly shown and unambiguously interpreted as a transition from endogenous respiration to the oxygen of the substrate. Moreover the basal rates of oxygen uptake before the addition of substrate and after its complete utilization were not significantly different. When allowance was made for the amounts of methyl ketone formed, almost quantitative balances $( \pm 10 \%$ ) were usually obtained by assuming that endogenous respiration was proceeding simultaneously and subtracting its value from the oxygen uptake in the presence of substrate. It was therefore concluded that endogenous respiration was not suppressed by the addition of non-toxic concentrations of fatty acids, which supports similar findings by Blumenthal (I963) with other Penicillium. spp. The validity of this assumption was supported by the finding that concentrations of 2,4-dinitrophenol up to $10^{-3} \mathrm{M}$ had no effect upon oxygen uptake, indicating that no significant oxidative assimilation was taking place. (Throughout this communication the term 'toxic' acid is defined as one that suppresses the oxygen uptake of mycelium relative to endogenous. It does not necessarily mean complete inhibition. Similarly a 'non-toxic' acid is, in this context, one whose presence does not inhibit oxygen uptake by mycelium.)

Different batches of mycelium grown under apparently identical experimental conditions sometimes showed markedly different rates of endogenous respiration and also oxygen uptake in the presence of the same amount of substrate. The rates were, however, similar in duplicate experiments using the same batch of mycelium.

\section{Metabolism of heptan-2-one}

As long as octanoic acid was available, it appeared that any heptan-2-one formed was not oxidized by the mycelium. Thereafter, however, the ketone was metabolized at a rate which apparently depended upon the age of the mycelium. A typical experiment showed that mycelium harvested after $72 \mathrm{hr}$ almost completely metabolised $0.4 \mu$ moles of heptan-2-one in $4 \mathrm{hr}$, whereas the same batch of mycelium harvested and tested $24 \mathrm{hr}$ earlier was only one tenth as active.

It was thought possible that heptan-2-one might be reduced to heptan-2-ol but it was found that less than $5 \%$ of the heptan-2-one was reduced to the methyl carbinol after $32 \mathrm{hr}$. On the other hand $90 \%$ of heptan-2-ol, at the same concentration, was oxidized to heptan-2-one in the same time.

\section{The effect of pre-shaking mycelium in buffer for extended periods}

Although endogenous respiration of mycelium was not usually markedly decreased, pre-shaking in buffer enabled the mycelium to oxidize fatty acid at concentrations which inhibited the oxygen uptake of freshly harvested mycelium (Table I). The oxygen uptake by,pre-shaken mycelium in the presence of non-toxic concentrations of octanoic acid (I $\mu$ mole) was also higher than with fresh mycelium but the yield of heptan-2-one was lower.

\section{Effect of phosphate on fatty acid oxidation}

Both oxidation of substrate and endogenous respiration were inhibited in the absence of phosphate during incubation of mycelium with fatty acids. Optimum phosphate concentration for oxygen uptake in the presence of fatty acids was about 
$0.0 \mathrm{M}$ with fresh mycelium and about $0.03 \mathrm{M}$ for mycelium shaken in phosphate buffer for $36 \mathrm{hr}$. This difference may be associated with the observed decrease in toxicity of fatty acids towards preshaken mycelium.

Effect of metabolic carbon dioxide on fatty acid oxidation

Decreases of up to $50 \%$ in the yield of methyl ketone were obtained by the removal of metabolic carbon dioxide as it was formed during incubation. The absorption of respiratory $\mathrm{CO}_{2}$ by alkali was not therefore a satisfactory measure of fatty acid oxidation since such methods of determining respiration are valid only if the cells follow the same pathways in the presence or absence of $\mathrm{CO}_{2}$ (Dixon, I95I).

Table I. The effect of preshaking the mycelium of Penicillium roqueforti on its ability to oxidize octanoic acid at $\mathrm{pH} 2 \cdot 5$

Each Warburg flask contained Io mg. dry wt equiv. mycelium, harvested after $65 \mathrm{hr}$, $50 \mu$ moles phosphate, $(\mathrm{pH} 2.5)$ and distilled water to $3 \mathrm{ml}$. Time of incubation $120 \mathrm{~min}$. The mycelium was either used immediately after harvesting or after being shaken in phosphate buffer, $\mathrm{pH} 6 \cdot 0$, for 15 or $20 \mathrm{hr}$.

$\begin{array}{lccccc} & \overbrace{\text { Endogenous }}^{\text {I } \begin{array}{c}\mu \text { mole } \\ \text { acid }\end{array}} & \begin{array}{c}3 \mu \text { moles } \\ \text { acid }\end{array} & \overbrace{\begin{array}{c}\text { I } \mu \text { mole } \\ \text { acid }\end{array}}^{\text {Oxygen Uptake }(\mu 1 .)} & \begin{array}{c}3 \mu \text { moles } \\ \text { acid }\end{array} \\ \text { Mycelium } & 155 & 285 & 22 & 0.45 & 0.32 \\ \text { Fresh } & \text { I } 40 & 351 & 104 & 0.19 & 0.50 \\ \text { Pre-shaken I5 hr } & \text { I45 } & 350 & 150 & 0.14 & 0.70\end{array}$

\section{Effect of concentration of fatty acid}

At any one $\mathrm{pH}$ value and for a given weight of mycelium it was found that there was an optimum concentration of acid for maximum oxygen uptake and optimum conversion to methyl ketone. Thus at $\mathrm{pH} 6.5$ and with $4 \mathrm{mg}$. dry wt mycelium maximum rates of oxidation were obtained with $3.5 \mu$ moles octanoic acid (Fig. I). Lower concentrations of this acid (I $\mu$ mole) were completely oxidized with almost no trace of heptan-2-one formation and in general increased oxygen uptake was found to occur at the expense of methyl ketone formation. Increasing the octanoic acid concentration above $3.5 \mu$ moles at this $\mathrm{pH}$ value decreased the rate of oxidation. A similar inhibitory effect was also obtained by using less mycelium, showing that the ratio of the number of hyphal cells to the fatty acid concentration determined the rate of oxidation. For the following studies, therefore, the weight of mycelium (Io mg.) used was that which would oxidize $3 \mu$ moles of octanoic acid completely at $\mathrm{pH}$ values between $5^{\circ} 0$ and 7.0 in $2-3 \mathrm{hr}$.

\section{Effect of $p H$ value}

The relative amounts of methyl ketone and respiratory carbon dioxide formed during fatty acid metabolism were dependent upon the $\mathrm{pH}$ of the incubation medium. At $\mathrm{pH} 2.5$ oxygen uptake was inhibited by $3 \mu$ moles octanoic acid, whereas at $\mathrm{pH} 6.0$ the same concentration of acid was rapidly oxidized with a lower yield of heptan-2-one. With increasing concentration of octanoic acid, the $\mathrm{pH}$ value at which oxygen uptake was a maximum also increased. Optimum $\mathrm{pH}$ values for the oxidation of $\mathrm{I}, 3$ and $25 \mu$ moles of octanoic acid by $10 \mathrm{mg}$. dry wt mycelium were $\mathrm{pH} 5 \cdot 0,5 \cdot 5$ and $6 \cdot 0$, respectively. 


\section{Oxidation of fatty acids with an even number of carbon atoms}

The rate of oxygen uptake by the mycelium increased immediately on the addition of $\mathrm{C}_{4}-\mathrm{C}_{12}$ fatty acids but formation of the corresponding methyl ketone was detected only after about $30 \mathrm{~min}$. (Fig. 2). The rate and pattern of oxidation was markedly dependent upon the $\mathrm{pH}$ value (Figs. $3 a-d$ ). At $\mathrm{pH} 2.5$ the rate of respiration by the mycelium in the presence of the $\mathrm{C}_{6}-\mathrm{C}_{12}$ fatty acids was less than its endogenous respiration, the maximum inhibitory effect being shown by decanoic acid (Fig. $3 a$ ); high yields

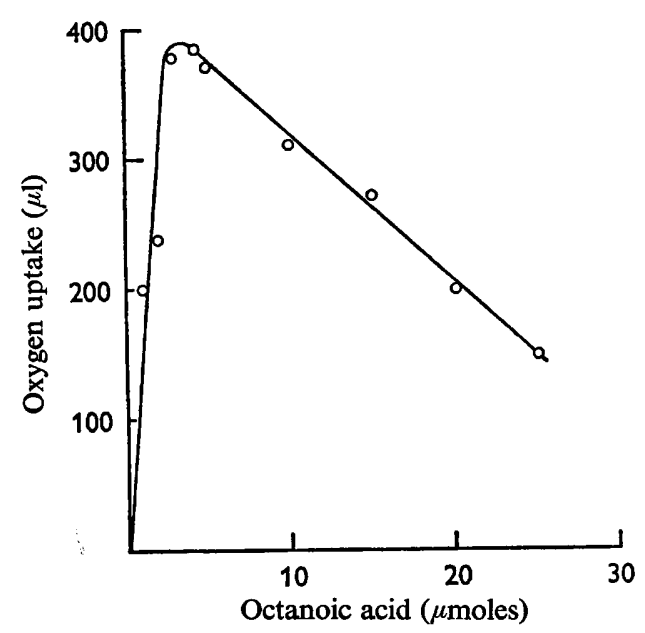

Fig. I

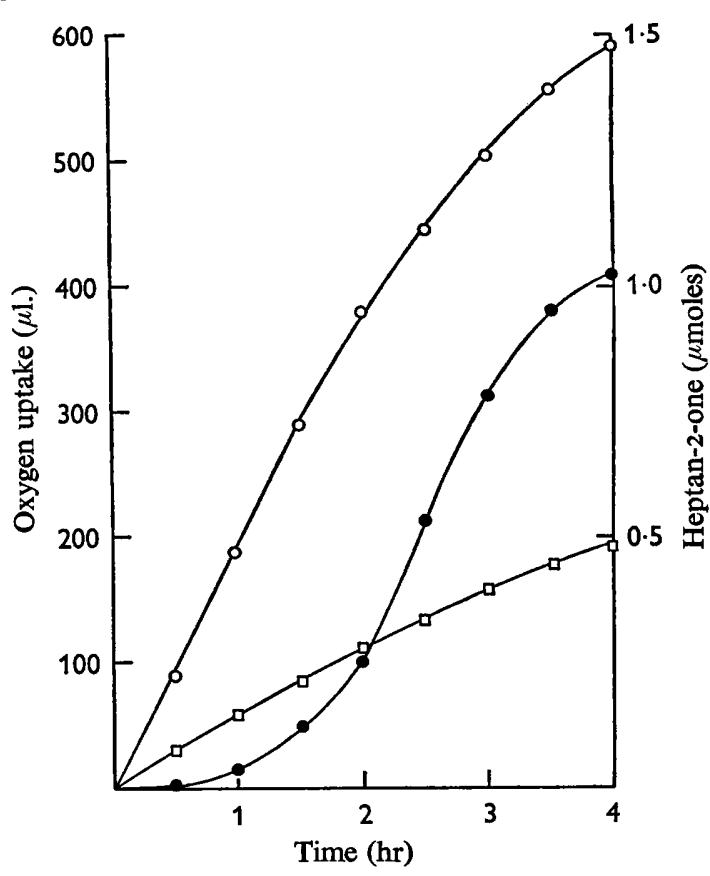

Fig. 2

Fig. I. The effect of concentration of octanoic acid on the rate of oxygen uptake by mycelium of Penicillium roqueforti. Reaction conditions: $4 \mathrm{mg}$. dry wt equiv. mycelium harvested after $48 \mathrm{hr}, 50 \mu$ moles phosphate buffer (pH 6.5).

Fig. 2. The rate of oxygen uptake $(\mathrm{O}-\mathrm{O})$ and methyl ketone formation (-0) by mycelium of Penicillium roqueforti incubated with $3 \mu$ moles octanoic acid. $\square-\square$, endogenous oxygen uptake. Reaction conditions: $10 \mathrm{mg}$. dry wt equiv. mycelium harvested after $48 \mathrm{hr}, 50 \mu$ moles phosphate buffer (pH 5*2).

of the corresponding methyl ketone with one less carbon atom were nevertheless obtained with the $\mathrm{C}_{6}-\mathrm{C}_{8}$ acids. At $\mathrm{pH} 5.2$ the pattern of oxygen uptake and methyl ketone formation was essentially the same as at $\mathrm{pH} \mathrm{2.5}$, except that $\mathrm{C}_{6}$ and $\mathrm{C}_{8}$ no longer partially inhibited endogenous respiration and that $\mathrm{C}_{12}$ acid was most toxic (Fig. $3 b$ ).

At $\mathrm{pH} 6.8$ rates of oxygen uptake in the presence of all fatty acids were greater than that of endogenous respiration, maximum uptakes being obtained with $\mathrm{C}_{8}$ and $\mathrm{C}_{10}$ acids as substrates. The yield of pentan-2-one from hexanoic acid was considerably less than at $\mathrm{pH} 5 \cdot 2$ (Fig. $3 \mathrm{c}$ ). At $\mathrm{pH} 8 \cdot 0$ oxygen uptake in excess of endogenous respiration and the yields of the corresponding methyl ketones were relatively low in the presence of all fatty acids. The rate of oxidation was greatest with $\mathbf{C}_{\mathbf{1 0}}$ acid as substrate (Fig. $3 d$ ) and least with $\mathrm{C}_{14}$ fatty acid. 
Shaking the mycelium in buffer for $48 \mathrm{hr}$ considerably increased the subsequent rate at which the mycelium oxidized the $\mathrm{C}_{6}-\mathrm{C}_{12}$ fatty acids at all $\mathrm{pH}$ values between 2.5 and 6.8 , although the relative yields of methyl ketone from each acid were not significantly different. The most toxic acid towards fresh mycelium at any one $\mathrm{pH}$ value was also the most inhibitory towards pre-shaken mycelium. The $\mathrm{C}_{14}-\mathrm{C}_{18}$ fatty acids were not oxidized to any significant extent by either fresh or pre-starved mycelium at any $\mathrm{pH}$.
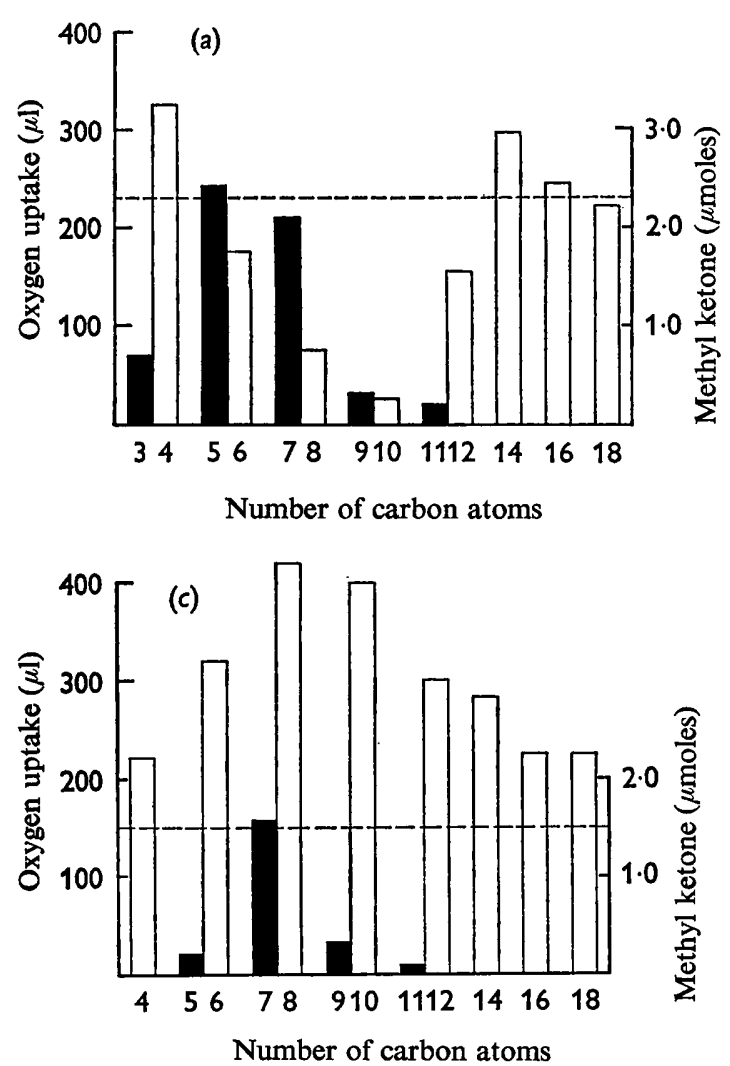
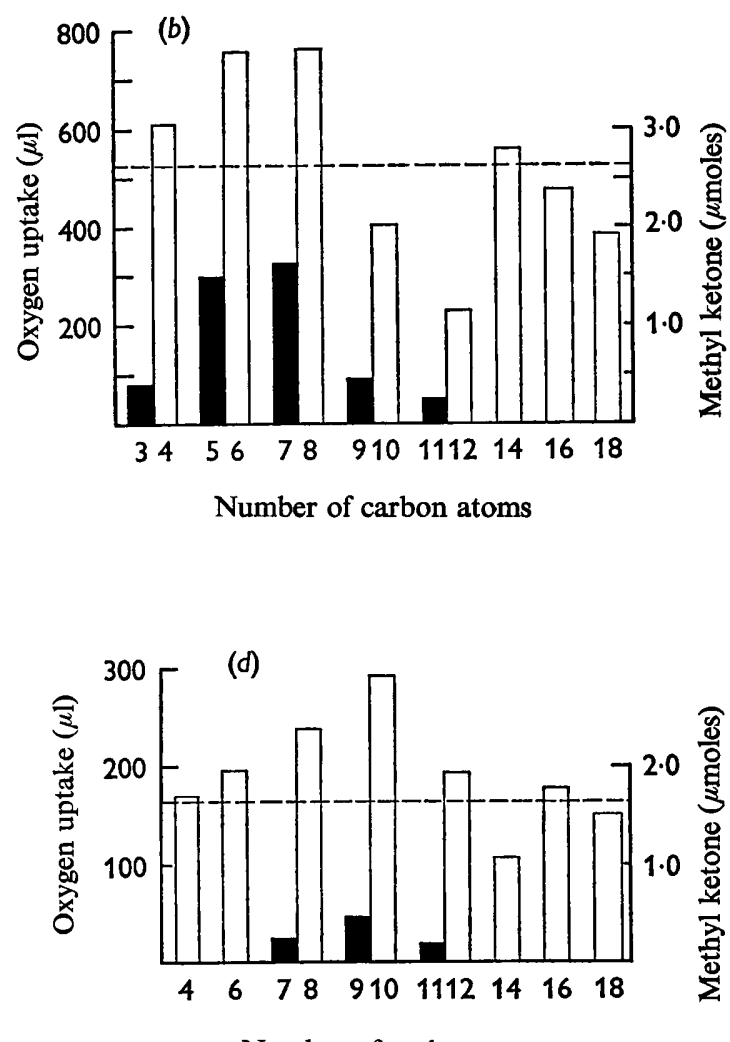

Number of carbon atoms

Fig. 3. The influence of chain length of fatty acids on the oxygen uptake (unshaded bars) and formation of methyl ketones (shaded bars) by mycelium of Penicillium roqueforti incubated with even numbered fatty acids in the range $\mathrm{C}_{4}-\mathrm{C}_{18}$ at $(a) \mathrm{pH} 2 \cdot 5,(b) \mathrm{pH} 5 \cdot 2,(c) \mathrm{pH} 6 \cdot 8,(d)$ $\mathrm{pH} 8 \cdot 0$. Reaction conditions: equiv. $10 \mathrm{mg}$. dry wt mycelium harvested after $66 \mathrm{hr}, 3 \mu$ moles of fatty acids, $50 \mu$ moles phosphate and distilled water to $3 \mathrm{ml}$. Endogenous respiration of the different batches of mycelium is indicated by the dotted horizontal lines. Even carbon numbers refer to fatty acid substrates and odd carbon numbers to the corresponding methyl ketone with one less carbon atom.

\section{Oxidation of fatty acids with an odd number of carbon atoms}

The pattern of oxygen uptake and of methyl ketone formation was very similar for fatty acids containing both an even and an odd number of carbon atoms from $\mathrm{C}_{3}$ to $\mathrm{C}_{11}$ (Fig. 4), suggesting that the oxidative pathway for all fatty acids is similar. 


\section{Mechanism of toxicity}

The mechanism by which the $\mathrm{C}_{6}-\mathrm{C}_{12}$ fatty acids inhibited oxygen uptake was examined with particular reference to a possible relationship between this toxic effect and the production from each acid of only the corresponding methyl ketone with one less carbon atom. The addition of toxic concentrations of $C_{10}$ or $C_{11}$ acid markedly suppressed the oxidation of non-toxic concentrations of $\mathrm{C}_{5}$ acid by freshly harvested mycelium, whether added at the same time or after oxidation of the non-toxic acid was proceeding normally (Fig. 5). In the latter case $C_{11}$ acid was more immediately effective in inhibiting oxidation of the $C_{5}$ acid than the less toxic $C_{10}$ acid but in both cases the formation of butan-2-one from the $\mathrm{C}_{5}$ acid was markedly increased, showing that oxidation proceeded as far as the $\beta$-oxo acid (Table 2).

A considerably higher yield of methyl ketone, however, was obtained from a non-

Table 2. The effect of toxic acids on the formation of methyl ketones from a non-toxic acid by mycelium of Penicillium roqueforti

Each Warburg flask contained Io mg. dry equiv. wt mycelium harvested after $60 \mathrm{hr}, 50 \mu$ moles phosphate buffer ( added $30 \mathrm{~min}$. later and incubation continued for a further $160 \mathrm{~min}$.

\begin{tabular}{lccc}
\multicolumn{3}{c}{ Fatty acid } & \multicolumn{3}{c}{ Methyl ketone $(\mu$ moles $)$} \\
$C_{5}$ & $C_{4}$ & $C_{5}$ & $C_{10}$ \\
$C_{10}$ & 0.19 & - & - \\
$C_{11}$ & - & 0.40 & - \\
$C_{5}+C_{10}$ & 0.39 & 0.37 & -16 \\
$C_{5}$ followed by $C_{10}$ & 0.39 & 0.35 & - \\
$C_{5}$ followed by $C_{11}$ & 0.90 & - & 0.20
\end{tabular}

Table 3. The effect of pretreating mycelium of Penicillium roqueforti with different amounts of $C_{10}$ acid for 1o or 40 min. on its ability to oxidize $C_{8}$ acid to heptan-2-one

Each Warburg flask contained $10 \mathrm{mg}$. dry wt equiv. mycelium (pretreated with 2-10 $\mu$ moles $\mathrm{C}_{10}$ acid for 10 or $40 \mathrm{~min}$. and then washed with phosphate buffer and distilled water) harvested after $48 \mathrm{hr}, 2 \mu$ moles $\mathrm{C}_{8}$ acid, $50 \mu$ moles phosphate buffer (pH 5.2). Period of incubation $120 \mathrm{~min}$.

$\begin{array}{ccccc}\begin{array}{c}\text { Pretreatment } \\ \text { (min.) }\end{array} & \begin{array}{c}\mathrm{C}_{10} \text { acid } \\ (\mu \text { moles })\end{array} & \begin{array}{c}\mathrm{C}_{8} \text { acid } \\ (\mu \text { moles })\end{array} & \begin{array}{c}\text { Heptan-2-one } \\ (\mu \text { moles })\end{array} & \begin{array}{c}\text { Oxygen } \\ \text { uptake }(\mu \mathrm{l} .)\end{array} \\ \text { I0 } & - & - & \text { Nil } & 179 \\ & - & 2 & 0.27 & 414 \\ & 2 & 2 & 1.53 & 68 \\ & 4 & 2 & 0.50 & 33 \\ 40 & 8 & 2 & 0.21 & 32 \\ & 10 & 2 & 0.10 & 30 \\ & - & 2 & 0.09 & 36 \\ & 2 & - & \text { Nil } & 202 \\ & 4 & - & \text { Nil } & 10 \\ & 2 & 2 & \text { Nil } & 3 \\ & 2 & 2 & 0.80 & 438 \\ & 4 & 2 & 1 \cdot 30 & 75 \\ & 6 & 2 & 0.24 & 15 \\ & 2 & 0.12 & 15\end{array}$


toxic acid by pretreatment of the mycelium with low concentrations of $\mathbf{C}_{\mathbf{1 0}}$ acid for short periods. This pretreated mycelium was collected on a Millipore filter and washed with $0.05 \mathrm{M}$-phosphate buffer $(\mathrm{pH} 7 \cdot 0)$ and distilled water. The mycelium was resuspended in $3 \mathrm{ml}$. phosphate buffer $(\mathrm{pH} 5 \cdot 2), 2 \mu$ moles $\mathrm{C}_{8}$ acid were then added and oxidation allowed to proceed for $2 \mathrm{hr}$. The use of mycelium pretreated with $2 \mu$ moles $\mathrm{C}_{\mathbf{1 0}}$ for $10 \mathrm{~min}$. resulted in a 6 -fold increase in yield of heptan-2-one (Table 3). Preincubation of the mycelium with $10 \mu$ moles $C_{10}$ acid for $10 \mathrm{~min}$., however, almost completely inhibited its subsequent ability to oxidize octanoic acid to heptan-2-one.

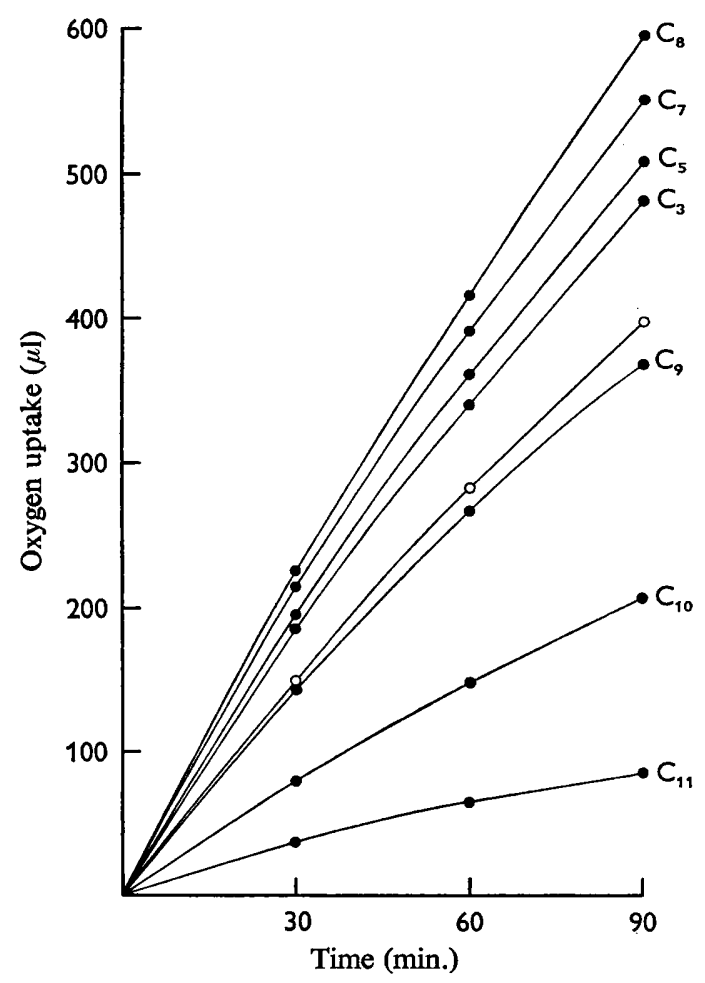

Fig. 4

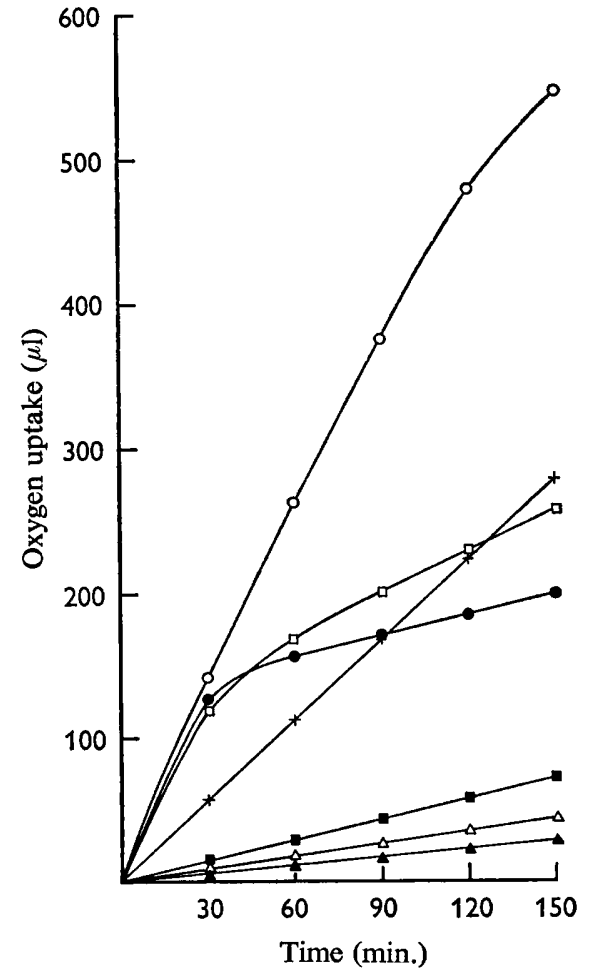

Fig. 5

Fig. 4. The oxygen uptake at $\mathrm{pH} 5 \cdot 2$ by mycelium of Penicillium roqueforti incubated with fatty acids with an odd number of carbon atoms in the range $C_{3}-C_{11}$, compared with rates for $C_{8}$ and $C_{10}$ fatty acids. Reaction conditions: Iomg. dry wt equiv. mycelium, harvested after $66 \mathrm{hr}$, $3 \mu$ moles of acid and $50 \mu$ moles phosphate buffer. $\mathrm{E}=$ endogenous respiration $(\mathrm{O}-\mathrm{O})$.

Fig. 5. The inhibition of oxygen uptake by the addition of $C_{10}$ or $C_{11}$ fatty acids to mycelium of Penicillium roqueforti incubated with $\mathrm{C}_{5}$ fatty acid. Reaction conditions: $10 \mathrm{mg}$ dry wt equiv. mycelium harvested after $48 \mathrm{hr}$., $3 \mu$ moles of each acid, $50 \mu$ moles of phosphate buffer and distilled water to $3 \mathrm{ml}$. Oxygen uptake in the presence of $C_{5}$ acid $(O-O), C_{10}$ acid $(\Delta-\Delta)$, $C_{11}$ acid ( $\left.\Delta \Delta\right), C_{5}$ and $C_{10}$ acid added simultaneously $(\square-D), C_{5}$ acid followed after 30 min. by $C_{10}$ acid ( $\left.\square-\square\right)$ or $C_{11}$ acid (- $\left.-\bullet\right)$; endogenous respiration $(x-x)$.

The extent of damage to the enzyme systems of the mycelium was also dependent, to a lesser extent, on the length of time the cells were subjected to the toxic effect of the $\mathrm{C}_{10}$ acid. Preincubation of the mycelium with $\mathrm{C}_{10}$ acid for $40 \mathrm{~min}$. resulted in a slightly lower rate of oxidation than mycelium pretreated with the same concentration of acid for $10 \mathrm{~min}$. (Table 3.) 
No ${ }^{14} \mathrm{CO}_{2}$ was detected when mycelium that had been pretreated with a toxic concentration of unlabelled $\mathrm{C}_{10}$ acid for $20 \mathrm{~min}$. was subsequently incubated with $\left[2-{ }^{14} \mathrm{C}\right]$ octanoic acid for $2 \mathrm{hr}$, whereas about $7 \%$ of the radioactivity was converted to ${ }^{14} \mathrm{CO}_{2}$ by untreated mycelium. The yield of $\left[\mathrm{r}-{ }^{14} \mathrm{C}\right]$ heptan-2-one was, however, three times greater with mycelium that had been pre-treated with $\mathrm{C}_{10}$ acid.

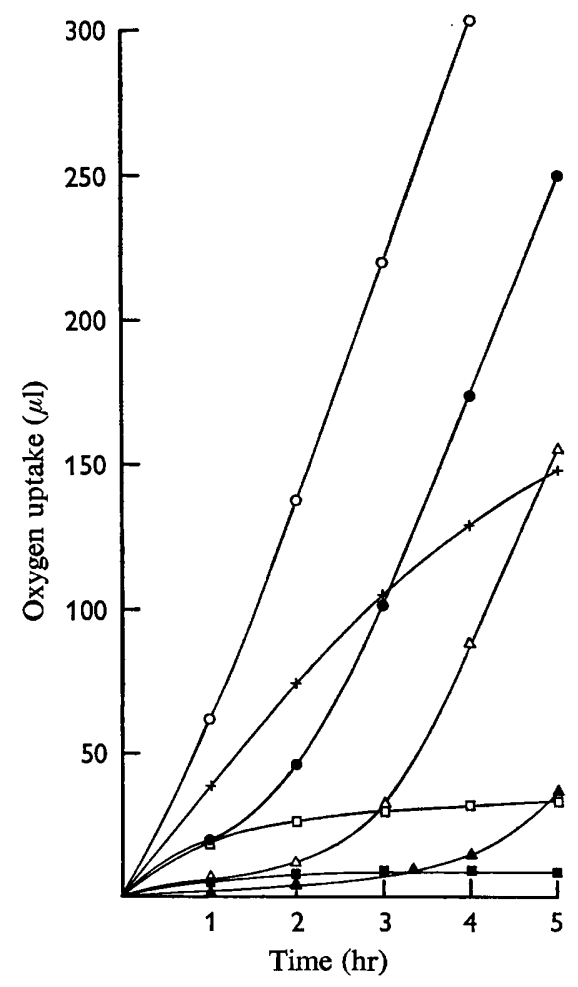

Fig. 6. The annulment of the inhibitory effect of octanoic acid at low pH value on the oxygen uptake of mycelium of Penicillium roqueforti by an increase in $\mathrm{pH}$ value. Reaction conditions: Iomg. dry wt equiv. mycelium harvested after $48 \mathrm{hr}, 50 \mu$ moles phosphate buffer and distilled water to $3 \mathrm{ml}$. Oxygen uptake of mycelium pretreated at $\mathrm{pH} 2.5$ for $\mathrm{I} \mathrm{hr}$ with $4 \mu$ moles $(\bullet-), 6 \mu$ moles $(\triangle-\Delta)$ and $8 \mu$ moles $C_{8}$ acid $(\Delta-\Delta)$ after addition of suffcient $\mathrm{KOH}$ to raise to $\mathrm{pH} 5.5$; Oxygen uptake in presence of $4 \mu$ moles $\mathrm{C}_{8}$ acid at $\mathrm{pH} 2.5$ ( $\square-\square)$ and $\mathrm{pH} 5.5\left(\mathrm{O}-\mathrm{O}\right.$ and of $6 \mu$ moles $\mathrm{C}_{8}$ acid at $\mathrm{pH} 2.5(\square-\square)$ also given; endogenous respiration $(x-x)$.

\section{Reversibility of toxic effect of fatty acids at low $\mathrm{pH}$ values}

Inhibition of respiration was almost instantaneous at $\mathrm{pH} 2.5$ when toxic concentrations of $\mathrm{C}_{6}-\mathrm{C}_{12}$ fatty acids were added to freshly harvested mycelium. This effect could be annulled, after a lag phase, by increasing the $\mathrm{pH}$ value of the reaction mixture to 5.5 for $\mathrm{C}_{6}$ and $\mathrm{C}_{8}$ acids and to $\mathrm{pH} 6.8$ for $\mathrm{C}_{10}$ and $\mathrm{C}_{12}$ acids. The length of the lag phase before oxidation proceeded depended on the concentration of fatty acid added (Fig. 6) and to a lesser extent upon the length of time the cell was in contact with the acid at $\mathrm{pH} 2 \cdot 5$. 


\section{Rates of formation of ${ }^{14} \mathrm{CO}_{2}$ from $\left[\mathrm{I}^{-1} \mathrm{C}^{4}\right]$ and $\left[2-{ }^{14} \mathrm{C}\right]$ octanoic acids}

The rate of appearance of ${ }^{14} \mathrm{C}$ in respiratory $\mathrm{CO}_{2}$ was ${ }^{\mathrm{I}} \cdot 7-3 \cdot \mathrm{I}$ times faster from $\left[{ }^{\left[{ }^{14}\right.} \mathrm{C}\right]$ octanoic acid than from $\left[2-{ }^{14} \mathrm{C}\right]$ octanoic acid, over $2 \mathrm{I} \%$ of the former and $7 \%$ of the latter being oxidized to ${ }^{14} \mathrm{CO}_{2}$ in $150 \mathrm{~min}$. at $\mathrm{pH} 6 \cdot 0$ (Table 4). No heptan-2-one was detected in the first $\mathrm{I} 20 \mathrm{~min}$. and only $0.05 \mu$ moles after $150 \mathrm{~min}$. A correction for the $0.05 \mu$ moles ${ }^{14} \mathrm{CO}_{2}$ formed in the decarboxylation of $\beta$-oxo octanoic acid had therefore to be applied in the latter instance.

Table 4. A comparison of the rate of appearance of ${ }^{14} \mathrm{C}$ in respiratory carbon dioxide during the oxidation of $\left[1-{ }^{14} \mathrm{C}\right]$ - and $\left[2-{ }^{14} \mathrm{C}\right]$ octanoic acids by mycelium of Penicillium roqueforti.

Each flask contained equiv. 10 mg. dry wt mycelium harvested after $48 \mathrm{hr}, 50 \mu$ moles phosphate buffer (pH 6.0), $1 \cdot 5 \mu$ moles of either $\left[I^{114} \mathrm{C}\right]$ octanoic acid $(43,500$ counts $/ \mathrm{min}$.) or [2-14 C]octanoic acid (44,750 counts/min.).

\begin{tabular}{|c|c|c|c|c|}
\hline \multirow[b]{2}{*}{$\begin{array}{c}\text { Time } \\
\text { (min.) }\end{array}$} & \multicolumn{2}{|c|}{$\begin{array}{l}{\left[{ }^{1-14} \mathrm{C}\right] \text { octanoic acid: }} \\
{ }^{14} \mathrm{CO}_{2} \text { formed }\end{array}$} & \multicolumn{2}{|c|}{$\begin{array}{l}{\left[2-{ }^{14} \mathrm{C}\right] \text { octanoic acid: }} \\
{ }^{14} \mathrm{CO}_{2} \text { formed }\end{array}$} \\
\hline & $\begin{array}{l}\text { Counts/ } \\
\text { min. }\end{array}$ & $\begin{array}{c}\text { Total } \\
\text { activity (\%) }\end{array}$ & $\begin{array}{c}\text { Counts/ } \\
\text { min. }\end{array}$ & $\begin{array}{c}\text { Total } \\
\text { activity (\%) }\end{array}$ \\
\hline 30 & 1150 & $2 \cdot 7$ & 500 & $I \cdot I$ \\
\hline 60 & 1955 & $4 \cdot 5$ & 1495 & $3 \cdot 3$ \\
\hline 90 & 4380 & $10 \cdot \mathrm{I}$ & 2234 & 50 \\
\hline 120 & 6365 & I4.7 & 2575 & $5 \cdot 7$ \\
\hline 150 & 9430 & $2 \mathrm{I} \cdot 7$ & 3185 & $7 \cdot 0$ \\
\hline
\end{tabular}

\section{Effect of malonate}

It was expected that the addition of malonate would inhibit the oxidation of fatty acids to carbon dioxide and thus possibly lead to an increase in methyl ketone formation. Various concentrations of malonate up to $0 \cdot I \mathrm{M}$, however, did not inhibit respiration of mycelium either in the presence or absence of fatty acids between $\mathrm{pH} 2.5$ and 6.0. Low concentrations of malonate at $\mathrm{pH}$ values less than $5^{\circ} \mathrm{O}$ actually increased the rate of oxygen uptake, indicating ability of the hyphal cells to metabolize malonic acid. Malonate was, however, an effective inhibitor of the high succinic dehydrogenase activity in cell-free extracts obtained by disintegrating the mycelium in a Hughes press. Similar findings have been reported with preparations from higher plants (Young \& Shannon, I959; Hatch \& Stumpf, 1962).

\section{DISCUSSION}

The rate of oxygen uptake by mycelium of Penicillium roqueforti increased immediately in the presence of low concentrations of $\mathrm{C}_{4}-\mathrm{C}_{12}$ fatty acids. The length of time for which the mycelium had been grown, however, greatly affected its ability to oxidize fatty acids to respiratory carbon dioxide. This is in agreement with the finding that the oxidation of acetate by the mycelium of $P$. urticae was markedly dependent upon the phase of growth at which it was harvested (Bu'Lock et al. 1965).

The rate of appearance of ${ }^{14} \mathrm{C}$ in respiratory carbon dioxide was $\mathrm{I} \cdot 7-3 \cdot \mathrm{I}$ times greater for $\left[\mathrm{I}^{-14} \mathrm{C}\right]$ than for $\left[2-{ }^{14} \mathrm{C}\right]$ octanoic acid, indicating the existence of a $\beta$-oxidative 
pathway in mycelial respiration (Katz \& Chaikoff, 1955), although carbon dioxide production from both acids was slow. The thiolase and deacylase reactions involved in the metabolism of fatty acids to respiratory carbon dioxide and methyl ketones respectively have a common intermediate, namely the $\beta$-oxoacylester. By analogy with other regulatory mechanisms it would appear that this first divergent step in fatty acid oxidation is the most likely point of cellular regulation. It is possible that the lag phase which occurs in methyl ketone formation, and the observed slow formation of ${ }^{14} \mathrm{CO}_{2}$ from $\left[2-{ }^{14} \mathrm{C}\right]$ octanoate, may result from a product inhibition of thiolase activity and consequent induction of either deacylases or $\beta$-oxo decarboxylases. In this event deacylation of the $\beta$-oxo acyl ester and subsequent decarboxylation of the $\beta$-oxo acid to methyl ketone would provide an alternative source of coenzyme A for further fatty acid activation when the oxidation of acetyl CoA formed in the thiolase reaction is impaired. Such a mechanism would explain why only a single methyl ketone with one less carbon atom was detected in the oxidation of a single fatty acid as substrate and would support the hypothesis that secondary metabolites are formed as a result of induced enzyme mechanisms (Bu'Lock \& Powell, 1965).

The lowest yields of methyl ketone were obtained with the $C_{9}-C_{12}$ fatty acids which were the most inhibitory to oxygen uptake by the mycelium. A possible explanation for this finding is that the $\beta$-oxo acyl esters of the $\mathrm{C}_{9}-\mathrm{C}_{12}$ acids are much less readily deacylated than those of the $\mathrm{C}_{4}-\mathrm{C}_{8}$ acids and that less coenzyme $A$ is therefore available in the system. This is supported by the marked decrease in formation of carbon dioxide and increase in production of heptan-2-one when octanoic acid was added to cells which had been shaken with low concentrations of the $C_{9}-C_{12}$ acids. It may also be significant that the $\mathrm{C}_{14}-\mathrm{C}_{18}$ fatty acids were not oxidized by the mycelium to any significant extent at any $\mathrm{pH}$ and that no corresponding methyl ketones were detected from these acids.

The present investigation has emphasized the importance of $\mathrm{pH}$ value on the toxic effects of the homologous series of fatty acids upon the mycelium of Penicillium roqueforti. $\mathrm{C}_{10}$ and $\mathrm{C}_{12}$ acids were the most toxic acids at $\mathrm{pH} 2.5$ and 5.2 respectively, whereas at $\mathrm{pH} 6.8$ none of the acids from $\mathrm{C}_{4}$ to $\mathrm{C}_{18}$ inhibited oxygen uptake. The most toxic acid at $\mathrm{pH} 8.0$ was $\mathrm{C}_{14}$ acid but it is possible that at alkaline $\mathrm{pH}$ values the toxicity is a result of a surface effect as distinct from the toxicity observed at $\mathrm{pH}$ values less than $6 \cdot 0$. The inter-relationship between the toxic action of fatty acids and $\mathrm{pH}$ allows a ready explanation of the apparent contradiction between the results of Rolinson (1954), who reported $\mathrm{C}_{8}$ and $\mathrm{C}_{10}$ fatty acids to be toxic to $P$. chrysogenum at $\mathrm{pH} 6 \cdot 3$, and those of Girolami \& Knight (I955), who found that at $\mathrm{pH} 7 \cdot 3$ these two acids stimulated oxygen uptake by $P$. roquefort $i$ to a greater extent than other acids. Similarly in this investigation the $\mathrm{C}_{9}-\mathrm{C}_{12}$ acids more actively inhibited the respiration of mycelium than other fatty acids at $\mathrm{pH}$ values below 6.0 but were the most rapidly oxidized at $\mathrm{pH} 8 \cdot 0$. Conversely the $\mathrm{C}_{3}-\mathrm{C}_{5}$ acids were most readily oxidized at $\mathrm{pH} 2 \cdot 5$ but least rapidly at $\mathrm{pH} 8 \cdot 0$.

The present work supports the hypothesis that the primary inhibitory effect of toxic compounds on fungal cells occurs after they have penetrated the cell wall (Cochrane, 1958). Cells pretreated with a toxic concentration of fatty acids and then thoroughly washed with buffer were capable of oxidizing non-toxic concentrations of fatty acids to the corresponding methyl ketone but not to carbon dioxide. Similarly the $\mathrm{C}_{6}-\mathrm{C}_{12}$ fatty acids inhibited endogenous respiration of the mycelium markedly at $\mathrm{pH}$ values below 
6.0 but were nevertheless oxidized to methyl ketones in high yield. This suggests that the toxic effect was not due to adsorption of the fatty acids on the cell wall but that the acids actually entered the hyphal cell. The observed variation with $\mathrm{pH}$ of the inhibitory effect of fatty acids on oxygen uptake by mycelium is most easily explained by assuming that only undissociated molecules of fatty acids are transported into the cell and that, at a certain concentration, they or their oxidation products are toxic.

\section{REFERENCES}

Blumenthal, H. J. (1963). Endogenous metabolism of filamentous fungi. Ann. N.Y. Acad. Sci. I02, 688.

Bu'Lock, J. D. \& Powell, A. J. (1965). Secondary metabolism: an explanation in terms of induced enzyme mechanisms. Experientia 21, 55.

Bu'Lock, J. D., Hamilton, D., Hulme, M. A., Powell, A. J., Smalley, H. M., Shepherd, D. \& SмIтH, G. N. (1965). Metabolic development and secondary biosynthesis in Penicillium urticae. Can. J. Microbiol. 11, 765 .

Cochrane, V. W. (1958). Physiology of Fungi. New York: John Wiley and Sons.

Dixon, M. (I95I). Manometric Methods. Cambridge University Press.

FRANKE, W. \& HEINEN, W. (1958). Zur Kenntnis des Fettsäureabbaus durch Schimmelpilze. I. Über die Methylketonbildung durch Schimmelpilze. Arch. Mikrobiol. 31, 50.

GeHRIG, R. F. \& KNIGHT, S. G. (1958). Formation of ketones from fatty acids by spores of Penicillium roqueforti. Nature, Lond. 182, 1937.

GeHRIG, R. F. \& KNIGHT, S. G. (I96I). Formation of 2-heptanone from caprylic acid by spores of various filamentous fungi. Nature, Lond. 192, 1185.

GeHRIG, R. F. \& KNIGHT, S. G. (1963). Fatty acid oxidation by spores of Penicillium roqueforti. Appl. Microbiol. II, I66.

Girolami, R. L. \& KNight, S. G. (1955). Fatty acid oxidation by Penicillium roqueforti. Appl. Microbiol. 3, 264.

HAMmer, B. W. \& BryaNT, H. W. (1937). A flavor constituent of blue cheese (Roquefort type). Iowa State Coll. J. Sci. Ir, $28 \mathrm{r}$.

HATCH, M. D. \& STUMPF, P. K. (1962). Metabolism of malonic acid and its $\alpha$-substituted derivatives in plants. Pl. Physiol. 37, I21.

Katz, J. \& Chaikoff, I. L. (I955). Synthesis via the Krebs' cycle in the utilisation of acetate by rat liver slices. Biochim. biophys. Acta 18, 27.

LAWRENCE, R. C. (1965a). Use of 2,4-dinitrophenylhydrazine for the estimation of micro amounts of carbonyls. Nature, Lond. 205, 1313.

LAWRENCE, R. C. (1965b). Activation of spores of Penicillium roqueforti. Nature, Lond. 208, $80 \mathrm{I}$.

LAWRENCE, R. C. (I966). The oxidation of fatty acids by spores of Penicillium roqueforti. J. gen. Microbiol. 44, 393.

MetCalF, L. D. (1960). Gas chromatography of unesterified fatty acids using polyester columns treated with phosphoric acid. Nature, Lond. 188, 142.

MeYers, E. \& KNIGHt, S. G. (1958). Studies on the nutrition of Penicillium roqueforti. Appl. Microbiol. 6,174 .

Neal, A. L., WeInstock, J. O. \& LAMPEN, J. O. (1965). Mechanisms of fatty acid toxicity for yeast. J. Bact. 60, 126.

REID, E. E. \& RUHOFf, J. R. In Organic Synthesis. Ed. by H. A. Blatt, Vol. 2. New York: John Wiley \& Sons.

Rolinson, G. N. (1954). The effect of saturated fatty acids on oxygen uptake by Penicillium chrysogenum. J. appl. Bact. 17, 190.

StARKLE, M. (1924). Die Methylketone im oxydativen Abbau einiger Triglyceride (bzw. Fettsäuren) durch Schimmelpilze unter Berücksichtigung der besonderen Ranzidität des Kokofettes. I. Die Bedeutung der Methylketone im Biochemismus der Butterranzidität. II. Über die Entstchung und Bedeutung der Methylketone als Aromastoffe im Roquefortkäse. Biochem. Z. 151, 37 I.

Stokoe, W. N. (1928). The rancidity of coconut oil produced by mould action. Biochem J. 22, 80.

Thaler, H. \& GeIsT, G. (I939). Zur Chemie der Ketonranzigkeit; über die Bildung von Methylketonen aus Fettsäuren durch Penicillium glaucum. Biochem. $Z$. 302, I21. 
VINZE, V. L. \& GHOSH, D. (1962). Oxidative metabolism of $P$. chrysogenum. II. Oxidation of fatty acids. Hindustan Antiobiotics Bull. $4,119$.

Whitmore, F. C. \& OTTERBacher, T. (1944). Organic Syntheses. Ed. by H. A. Blatt, vol. 2, p. 317. New York: John Wiley and Sons.

Young, R. H. \& Shannon, L. M. (1959). Malonate as a participant in the metabolism of bush bean leaves. Pl. Physiol. 34, I49. 